\title{
SMPD2 Gene
}

National Cancer Institute

\section{Source}

National Cancer Institute. SMPD2 Gene. NCI Thesaurus. Code C105022.

This gene is involved in sphingomyelin catabolism. 